\title{
The Unnecessary Conflict: Resolving the Forestry/Wilderness Stalemate
}

by

\author{
R. Michael M'Gonigle ${ }^{1}$
}

\section{Abstract}

In British Columbia and throughout the world, conflicts between forestry and wilderness preservation are escalating. To some degree, this conflict reflects an intellectual conflict within forestry itself. This paper reviews and evaluates the present forestry "paradigm", and presents an emerging paradigm which is better able to resolve this and other new conflicts in forestry.

\section{Résumé}

En Colombie-Britannique et ailleurs dans le monde, les conflits surgissent entre la foresterie et la préservation des grands espaces. Jusqu'à un certain point, ce conflit souligne un antagonisme intellectuel au sein même de la foresterie. Cet article revise et évalue l'actuel "paradigme" forestier et présente un nouvel exemple mieux adapté à résoudre cet antagonisme ainsi que tous les nouveaux conflits en foresterie.

\section{Introduction}

In many parts of Canada and around the world, conflicts between industrial forestry and wilderness preservation are escalating. Nowhere is the conflict more evident than in British Columbia where wilderness/logging disputes such as Meares Island, South Moresby, the Stein River and the Carmanah Valley have become household names. Only last December, a coalition of environmental groups published a map staking out over 100 areas they wished to see set aside in perpetuity from any type of industrial activity, an action that would increase the amount of protected land in the province from 5 to $13 \%$ of the total land base (Valhalla Society 1988).

This rising level of environmental land use conflict is occuring at a time when politicians, academics and the media have begun to debate the need for a new era of ecologically "sustainable development". This concept emanates from a growing perception that our present course of action is pushing the planet to the brink of environmental collapse. As Lester Brown of the Washington-based Worldwatch Institute put it: "We are losing at this point, clearly losing the battle to save the planet. (Failure) will shake the world to its foundation." 2 In response, there is a perceived urgency to integrate ecological and economic planning to avoid this global crisis, an integration that poses a broad challenge to traditional patterns of thought and action.

Paradoxically, this challenge also presents an opportunity - one that might let us resolve outstanding conflicts like that between timber production and wilderness conservation. In this article, I shall review and criticize the approach to forestry that we have inherited from the past, and postulate how that approach might be altered to fit better into the emerging era of sustainable development. With such

\footnotetext{
The author, an environmental lawyer and political economist, is Assistant Professor Natural Resources Management Program, Simon Fraser University, Burnaby, B.C. V5A 1 S6. An earlier version of this paper was presented in the "Students for Forestry Awareness" lecture series, Faculty of Forestry, University of British Columbia.

${ }^{2}$ Lester Brown, author of the State of the World Report, 1989. Washington, D.C.: Worldwatch Institute. Quoted in The Globe and Mail, March 22, 1989: A3.
}

an alteration in perspective, the conflict between forestry and wilderness, which seems so irresolvable from the traditional forester's perspective, may well prove unnecessary in the future.

\section{The Challenge of Sustainable Development in Forestry}

The idea of sustainable development emerged onto the centre of the political stage with the publication of Our Common Future, the report of the United Nations World Commission on Environment and Development (1987). Concern about the ecological sustainability of temperate and tropical forestry was one issue among many discussed in the report. The report also called for drastic changes in other industrial sectors such as food, energy, transportation, urban planning and, indeed, in the entire thrust of economic development and political decision-making.

Planning for sustainable development requires us to re-examine our assumptions in many areas, to rethink fundamentals that we have long held dear. Such re-examinations are the norm for the progress of knowledge. We tend to think of knowledge as accumulating in some linear fashion, one discovery building on the base of the previous discoveries. In fact, as Kuhn (1962) demonstrated, the physical and biological sciences have repeatedly gone through revolutions in thought. One particular structure or framework of thinking (a so-called "paradigm") inevitably dominates a period of intellectual activity. Shared by the scientific community, the paradigm is so intricately interwoven with the values, techniques and achievements of that community that it defines those problems and solutions that are deemed worthy of consideration. Though the paradigm may have worked well for an entire generation's research, it is eventually challenged and overthrown by a new paradigm. The process of this change is not smooth, and involves institutional, as well as intellectual, struggle. But the result is eventually accepted, in part because the new paradigm is more adept at resolving exactly those uncomfortable problems that perplexed practitioners of the old paradigm, and which, with time, took on such importance that they could not longer be ignored. 
As a basis from which to approach the challenge of sustainable development in forestry, it is rewarding to apply this concept of "paradigm conflict" to the escalating controversy between professional foresters and their environmentalist critics. For at stake in the issue of competing land use allocations is actually the nature of the paradigm which we bring to decisions about forest land use and management. To resolve the forestry/wilderness stalemate requires not only a physical, but also an intellectual accommodation. When this latter accomodation is made, resolving the physical conflict becomes much easier.

\section{The Contemporary Forestry Paradigm}

To start, let me briefly characterize the industrial forester's worldview, or paradigm. This is, of course, a generalized and necessarily not unbiased view; it is the view of an informed outsider. It is based upon both the author's participant/observer status in the wilderness/forestry conflict in British Columbia over the last decade, as well as his work as an academic in the resources management field.

The forestry paradigm can be broken down into five attributes. First, the forester (and his or her work) is rational. That is, the discipline of forestry is a scientific one, based on established scientific principles. The field is interdisciplinary, drawing on many physical and biological sciences (mathematics, biology, ecology, genetics), on the applied sciences (engineering), and even on the harder of the social sciences (especially resource economics). Forestry practice is scientific as well (and, in execution, an art), at least to the extent to which field work is done on a systematic basis, and with careful monitoring to allow for a degree of precise experimentation. In this way, experience serves as a basis for the modification of those theories and educational principles that underpin the field. Increasingly as well, forestry is a complex science beholden to the techniques of mathematical modelling and systems analysis.

Second, the forester is a professional. That is, the forester's trained scientific expertise produces a body of shared knowledge, a common language and understanding of problems, and a shared institutional affiliation that unites the individual into a larger community of public responsibility (Steinbeck 1988). In practice, this professionalism is most evident in the acceptance of an institutionally-mandated moral code of conduct, in British Columbia, the Registered Professional Forester's Code of Ethics.

Third, in the practical world, the scientific and professional work of the forester is of a managerial nature. Employed as management in corporations or government bureaucracies, the forester-as-manager is concerned more with "means" than with "ends". In this situation, the board of directors or the provincial cabinet sets the ends according to some corporate or governmentally-mandated objectives, leaving the forester/manager with the more value-neutral task of devising the most efficient, cost-effective, or scientificallysound method of giving effect to that objective. With management objectives determined elsewhere, the forester is merely the public (or private) "servant". Maintaining this distinction between value-laden ends and neutral (or rational) means is fundamental to the characterization of management as based on a set of scientific (as distinct from moral or normative) techniques (Banfield 1959). The professional forester's application of his or her expert knowledge is simply one variation of this well-accepted principle of management theory and applied science.
These three attributes-rationality, professionalism, managerialism - contrast sharply with the foresters' perceptions of the wilderness advocate. These individuals are seen as irrational, driven by highly personal values or even spiritual passions, and appealing to the emotions of the citizenry. They are unprofessional, manipulating the citizen and the media, making exaggerated unscientific statements, and resorting to civil disobedience when their demands are not met. In contrast to the manager who must systematically balance the varied objectives which he or she is charged to implement, the preservationist is seen as a single-interest pressure group seeking to impose his or her particular values and objectives (ends) on the larger society. As Lloyd Forman, a logging contractor and leading opponent of the preservation movement for the Stein Valley in southern British Columbia, put it:

I told them (the Council of Forest Industries) that the other side (environmentalists) does such an effective job because they are out there pumping emotion, emotion, emotion. Instead, all the meetings you have here are using logic, logic, logic. And every time logic takes on emotion, logic loses...

We're being attacked by religious fanatics, no question about it. ${ }^{3}$

A fourth component of the forester's paradigm is the perception that the industry and the profession are vital. British Columbia has been built on the output of the forests, and the economy of the province is still sustained by it. A recent study by the Council of Forest Industries of B.C. (1989) argued that the industry provides 85000 direct jobs which, when indirect jobs are included, accounts for $17 \%$ of the province's workforce. According to this report, $\$ 2.7$ billion is paid annually by the industry to all levels of government in the province, that is, $\$ 1$ for every $\$ 5$ generated by the entire industry.

This vital contribution by the industry to provincial economies exists in varying degrees across the country. Nationally, it has been estimated that $\$ 25.8$ billion of Canada's Gross Domestic Product (that is, $9.3 \%$ of the country's collective revenue) and 834000 jobs (or $7.8 \%$ of total employment) were generated in 1980 by both the forest industry and those industries indirectly dependent on it (Jacques and Fraser 1989). In contrast, wilderness advocates are seen as comfortable urban professionals, yuppies, insensitive to rural employment and to the future of the industry that sustains them all.

Finally, and as a culmination of the above characteristics, foresters perceive themselves as responsible for the public welfare. In their roles in large forest corporations and government bureaucracies, foresters are charged with managing a significant proportion of the provincial land base, with balancing the demands of many competing values and interests, and with ensuring the economic stability of many forest-dependent towns throughout the provincial hinterland. In British Columbia, this responsible image has been publicly projected in a controversial series of corporate-interest advertisements, the "Forests Forever" campaign. As the Victoria Times-Colonist editorialized:

(This is) an industry endowed with noble qualities, of corporate responsibility and sensitivity to the environment. They stress reforestation priorities, the idyllic coexistence of industry, the ecology, recreation and tourism. The lead players include genial concerned

"Lloyd Forman, 1988. Quoted in "Understanding the Share groups: share our resources: share our forests; share the Stein". 1989 For. Plan. Cda. 5(1): 5-8. 
loggers and lab technicians-just the kind of people you'd like to have for neighbours. ${ }^{4}$

This paradigm is accurate, but only partly so. As C.S. Holling (1978), the former University of British Columbia ecologist, is fond of saying, we each carry "myths" about ourselves in our heads, myths which are neither completely accurate nor completely wrong, merely partial. Nevertheless, the myths impede progress unless we are able to step back from them, and change them where we confront evidence to the contrary.

\section{The Paradigm Revisited}

\section{Rationality, Values and Uncertainty}

If the forester today is rational, the issue remains: rational for what objectives? Rationality describes only a process, a logical or empirical procedure in the service of some other goals which are themselves never purely rational. It is to these objectives - be they the cutting of old-growth forests to make room for faster-growing second growth plantations, or the preservation of old-growth forests as genetic and educational reserves - to which reference must be made before rational procedures of resource extraction or conservation can be justified. As one BC forester put it: "Forestry is not just about how you build a forest road or grow a seedling or visit a wilderness. Forestry is much more. It is about why the road should be built, the seedling grown or the wilderness allocated in the first place".5

Only when one looks at the "why" as well as the "how" can the rationality of the industrial forester be critically assessed and understood. For example, within the profession, many forest economists now question the past objective (it is actually more like an unconscious assumption) that maximizing industrial timber benefits meant maximizing the volume of timber production. However, considering the goal of such production is an economic one, this assumption is itself now seen as inappropriate (i.e. not rational) in comparison with maximizing the economic value of such production. Thus, even without questioning the basic "why" (or objective) of profitable wood manufacture, changing the basic assumption of "how" this is met demands different rational tools of the forester, opening up his approach to an array of new intellectual and institutional considerations.

More broad, however, are the other values (why) for which forests are to be managed rationally. Here, one confronts the critics outside the profession who question the commitment of the forester to the multiple management goals set out under Section 5 of the BC Forest Act (Pearse 1986). These include timber production, but also wilderness-oriented recreation, water, fisheries and wildlife protection and so on. The divergence of perspective here is quite extreme when one considers, for example, that many foresters see any areas protected from logging as being "wasted", or locked up for "preservation and non-use".

Here again, meeting these diverse objectives demands an array of rational tools. For example, if water, fisheries and wildlife management issues were given greater weight than they are at present, the very nature of the forester's rationality would have to change. For example, tools that give a better understanding of the role of old-growth forests and representative ecosystems for long-term ecological stability

\footnotetext{
"Victoria Times-Colonist, 1988. The editorial is quoted in "Truth in advertising - the Forests Forever saga", 1989 For. Plan. Cda. 5(1): 25.

${ }^{5}$ Ray Travers, 1988. Some guidelines for better forest use decisions. Victoria TimesColonist. March, 1988.
}

and productivity would be more advanced than they are today. Instead, despite the political controversy with conservationists throughout Canada on these points, scientific expertise on old-growth ecology remains almost totally undeveloped in our forester's intellectual framework. This contrasts sharply, for example, with the developing state of research by American forestry academics and senior personnel in the US Forest Service. (Harris 1984, Franklin 1988)

Any serious evaluation of the forester's claim to rationality must, therefore, be situated within the context of his or her assumptions and objectives, primarily the assumption of forests-as-fibre, and forestry as the science of commodity production. But current concern for sustainability-including a growing concern for the consequences of our reliance on science and technology - demands a larger view. In the past, our scientific progress has tended to emphasize what we know, not what remains uncertain. When the frontier was still distant, and the scale of our activities still relatively small, the impacts of our actions were easily accomodated by an environment that seemingly had no bounds. But the scale of our interventions has grown, as have the surprising consequences of these interventions. From the innocent aerosol cans that turned out to be consuming the earth's protective ozone layer to the unexpected crashes of so many fish stocks throughout the world, the experience of the last few decades tells us that we need to put great emphasis on uncertainty in our science.

This has special significance for our applied sciences, such as high volume forestry. Today, serious uncertainties pervade the entire industrial forestry strategy. For example, justification for the presently high rate of allowable cut depends on poor data and debatable assumptions about the success of intensive silviculture (Boisvert 1987). The longterm survivability of the "re-designed" monocultural forests, which follow from this cut and on which the industry will increasingly depend in the years ahead, is now being questioned (Maser 1988). Meanwhile, in one of those all too typical "surprises" which are appreciated only when the damage has been done, only now are we beginning to understand the widespread detrimental impacts that large-scale clearcuts have on the ecological integrity of the fragmented patches of old growth which remain after cutting (Harris 1984, Franklin and Forman 1987. Noss 1988). In short, across the board, the rationality of modern industrial forestry ultimately rests on faith, hope and only a little data.

\section{Professionalism and Ideology}

Like the rationality on which it is founded, so too the conception of forestry as a profession has many hidden dimensions. As explained above, a profession is "a calling requiring specialized knowledge and often long and intensive academic preparation; a principal calling, vocation, or employment; the whole body of persons engaged in a calling" (Webster's Dictionary 1987). Inherent in this definition is that of a group with both shared private interests and public responsibilities.

How the group resolves the tension between private interests and public duties is the sort of process that sociologists analyze in terms of power and ideology. For example, the American sociologist Margali Larson (1977, p.243) suggests that the very concept of profession is not neutral, but instead describes a special interest group whose power and prestige rests upon a "monopolized competence and the undemocratic uses of expertise" and the "factual demonstration that knowledge is beneficient power."

When examined in this light, the paradigm of the Registered Professional Forester becomes more controversial. 
For example, with a shared language, training, and allegiance to common institutions, professionals are often unwilling to take seriously, or even listen to, other entrants to the debate. Such attitudes permeate all professions to some degree, surfacing, for example in the institutional battles of doctors with chiropractors and midwives (whom they see as either quacks or incompetents), or in the well-known intellectual disdain of the economist for the non-economist. It is evident too among foresters who question the ability of the non-specialist resource manager to speak authoritively about forestry. Without the letters RPF after one's name, credibility is suspect. This professional bias surfaces repeatedly in responding to the opinions of the non-expert public, especially the environmentalist with his or her different values and concerns. In short, while professionalism may stand as evidence of a commitment to rationality and responsibility, it may also pose an obstacle to respectful democratic debate and to the cooperative accomodation of diverse insights and understandings.

This obstacle may operate internally as well. One function of the professional association is to maintain discipline among members, for example, by controlling incompetence. But it can also become a means for punishing those perceived as disloyal to group interests especially where their actions bring into question the activities of other individual members. As Kuhn (1962) showed so dramatically, the collegial association can even stifle innovative research that does not fit the accepted paradigm. For example, one leading economist of a new school of sustainable "steady-state" economics criticized his profession's unwillingness to take seriously his theoretical challenges to their received neoclassical assumptions. This unwillingness, he charged, stemmed from "a powerful and well-entrenched establishment determined to defend at all costs the type of economics by which virtually all its members climbed to the summit" (Georgescu-Roegen 1981, p.193).

In British Columbia, it is in exactly these terms that the role of the professional forestry association is now being debated. Forestry research is criticized as still heavily focused on those fields useful to the received model of large-scale corporate forestry, with other areas (such as selective logging) dismissed as "uneconomic" or "unrealistic". One study of a badly mismanaged northern tree farm led the forester undertaking the study to make allegations of gross mismanagement against the foresters in charge. The outcome of his allegations was an acrimonious investigation by the professional association of his conduct, not the conduct of those he had accused. The forester's conclusions were later confirmed by the provincial ombudsman (Ombudsman 1987), and the allegations of unprofessional conduct against him were unsuccessful (Hopwood et. al. 1988). No charges were ever made against those responsible for the mismanagement. These issues of private actions and public accountability are the source of continuing dispute between environmentalists and the professional association.

\section{Whose Manager?}

Just as the concept of professionalism has an ideological aspect to it, so too the conception of "management" has an inherent implication that is rarely considered. That is, the rise of professionalism and the growth of management are both aspects of a single process of social and institutional centralization. Historically, the evolution of a new class of managerial professionals has gone hand-in-hand with the growth in both the size and impact of our society's economic and political institutions (Galbraith 1967). These institutions may become so self-interested that they resist redirection even when their activities have become demonstrably harmful to broader social welfare concerns.

In such a situation, the self-perception of the manager and the growth ethic of the organization in which that manager operates cannot be divorced. This applies across all economic sectors, including forestry. The history of BC forestry bears this out. In 1945, due to a concern about the unsustainable pace of the then-current level of cut, the second Royal Commission on BC forestry (the so-called Sloan Commission) introduced to British Columbia the policy of "sustained yield". At the time, the annual cut was about 20 million $\mathrm{m}^{3}$. In 1987, the Long Run Sustained Yield was estimated to be 55 million $\mathrm{m}^{3}$, the allowable annual cut was set at 75 million $\mathrm{m}^{3}$, mill capacity was estimated to be about 100 million $\mathrm{m}^{3}$-and the actual cut was about $91 \mathrm{million} / \mathrm{m}^{3}$. This was over three times the level on public lands that caused so much concern 45 years earlier, an increase which cannot be accounted for by such things as improved utilisation (Politics and Policy 1988).

Where the actual cut is so much closer to milling capacity than to levels of sustained yield, the lot of the manager is not an easy one. On the one hand, the manager faces the so-called "falldown effect" as timber supplies begin to run out; on the other hand are the omnipresent needs to increase productivity, achieve ever greater economies of scale, and expand throughput. These needs, though putting still greater pressure on the resource base, are the driving forces of the corporate organizations in which the manager works.

The pattern is a common one. For example, despite the greenhouse effect, there are compelling economic reasons for a continuing growth in $\mathrm{CO}^{2}$ emissions unless important generators of social wealth (automobiles and the energy sector) are to be transformed fundamentally. Similarly, despite the threat to thousands of lakes and millions of acres of productive forest land, legitimate economic obstacles exist for the failure of thermal generating plants, smelters and steel mills in the depressed Ohio Valley to reduce acid rain. Despite the existence of these realistic impediments, the devastating impacts on environmental and economic sustainability continue to grow.

Of necessity, management responds as much, if not more, to economic demands as it does to ecological requirements. What weight one assigns to either of these values in British Columbia helps determine where one sits on the spectrum of resource conflict. To be sure, environmentalists will not be held accountable for our economic success or failure, and are thus free to take the moral high road. For the forest manager, however, the predicament remains and weighs heavily on what is acceptable in his or her paradigm. In particular, if a "solution" exists that allows one to avoid the choice between environmental and economic values, that solution will tend to be favoured. And so, from electric cars to intensive silviculture, our faith in the technical fix emerges. Across our entire industrial landscape, this faith flows, however, as much from a discomfort at seriously considering the character of our unsustainability as it does from an evaluation of the true implications of this situation.

\section{How Vital?}

The enormous contribution of the forest industry to the growth and maintenance of the British Columbia economy is an oft-repeated truism of West Coast cultural lore - 
" 50 cents of every dollar" is the time-honoured cliche heard since childhood. While this particular number is exaggerated, the industry is of great importance, directly contibuting about $13 \%$ in boom years and $9 \%$ in lean years to the province's gross domestic product (BC Economic Accounts 1971-1984). But other questions arise about the vitality of this contribution.

First is the increasing concern that the contribution is not vital enough. Those small businesses that compete for timber through a competitive market have traditionally contributed a far greater proportion of stumpage fees to the provincial treasury than have the large integrated corporations with their guaranteed quotas. For example, in 1986-87, over $34 \%$ of the stumpage was paid by small timber companies competitively bidding for less than $9 \%$ of the timber cut, a disproportionately high stumpage level compared with the major tenure holders (although this was accounted for somewhat by the greater silvicultural responsibilities of these larger companies) (BC Min.For. 1987). While this proportion has changed with recent alterations in the stumpage formula, the historic discrepancy in the contribution attests to a continuing concern about the reliance on the non-market appraisal system used to collect provincial resource rents from large tenure-holders (Schwindt 1987).

In addition to uncollected resource rents is the oft-stated claim that British Columbia lags behind other jurisdictions in the jobs and income generated by a given volume of timber cut. Other provinces and foreign producers like Sweden and the United States have higher lumber recovery factors, create more jobs per unit of wood, invest many times more monies in research and development, add greater value to the wood product, and so on. For example, in Ontario, \$219000 and 7.7 jobs are created in the province for every $1000 \mathrm{~m}^{3}$ of wood cut. In B.C., only $\$ 97,000$ and 2.6 jobs are created for the same volume (Jacques and Fraser 1989). In short, the extent of the vitality of the provincial industry is by no means agreed.

In the forestry/wilderness debate, these arguments about just how vital is the contribution of the forest industry are heard time and again. A second question is also now showing increasing prominence: Is lumber production the only vital forest resource? In the forestry/wilderness debate, the growing role of the tourist industry is often mentioned as a counterbalance to a declining forestry employer. In the last decade, the number of unionized employees in logging, sawmilling, plywood and remanufacturing has decreased by $31 \%$, from 52 539 in 1979 to 36241 in 1988 (Vancouver Sun 1989). In contrast to the steadily shrinking work force in the forest industry (which stood at less than 85000 in 1989), tourism now employs over 100000 workers, and is growing. (Tourism Canada 1988). Of this, wilderness tourism is the fastest growing segment, expanding at some $17 \%$ per year (Outdoor Recreation Council 1988). Moreover, tourism is touted as the only form of employment that returns more money to the rural economy than it takes out, while it helps to diversify these economies from a single-industry resource dependency.

In short, while the vital contribution of the forest sector is recognized by both sides in the debate, questions remain about the degree to which that vitality has been developed, and about the desirability of achieving an accomodation with other economic sectors that are not only equally dynamic, but growing. These other sectors will increase in importance as the forest industry heads toward the reduction associated with the falldown effect.

\section{Responsible for the Future?}

Foresters have clearly played a central role in developing and managing one of the most prosperous economies in the industrialized world. However, as in almost every facet of our economic life, this prosperity has been achieved by relying increasingly upon large multi-national corporations. Today these institutions have sufficient power to influence those very government policies that are supposed to ensure that they operate in the public interest. With the limited convergence between narrow corporate interests and broad public goals, this situation threatens the forester's ability to make a truly responsible contribution to public welfare.

With the privatization today of many functions of the BC Forests Ministry service, public overview is declining even further in favour of private management. This puts enormous pressures on the company forester who, through a Letter of Understanding with the provincial government, is now responsible for carrying out even more of the public mandate as a private actor. He or she is publicly obligated to consider non-monetary timber values, and the economic interests of other groups (such as tourist operators) even though these public values bear no relationship to (and may indeed conflict with) the private economic objectives of the corporate employer. The conflicts inherent in this situation again call into question the ability of the professional forest manager to fulfill his or her public responsibility, especially as public demands increase in the age of sustainable development.

\section{Resolving the Forestry/Wilderness Stalemate}

In this new age, the true conflict that we face is not one between foresters and environmentalists, but one between the patterns we have all inherited from the past and the practices we must now adopt to ensure sustainability in the future. Making the necessary changes implies a fundamental shift in our management paradigm. As one American forester wrote recently, "real revolutions are needed to obtain good management of all our forests to benefit all of us" (Minckler 1989 p.63).

\section{Toward a Larger Rationality}

In this situation, a larger conception of rationality is called for. This larger rationality requires foresters to be more open than in the past to a wider range of values and objectives for the forest (Pearse 1986). In a time of change, old values must be re-assessed and new ones considered carefully. Today, we are confronted with the challenge of consciously re-designing those structures that will allow life on earth to be sustained. In this context, a broader rationality must put great emphasis on values that will allow that paramount objective to be achieved. These include values that support the maintainence of biotic diversity, ecological stability, climatic moderation, and resource productivity (Perry and Maghembe 1989) as well as planning objectives which, over many generations, are capable of returning an optimum level and mix of social and economic benefits from a limited resource base. In this light, some critics demand major changes in forest practices, such as those who claim that "the greatest single threat to biological diversity on earth...is habitat or forest fragmentation" (Noss 1988).

To begin with, our situation calls for a re-examination of those values that provide the justification for applied scientific pursuits such as forestry. Second, however, in this age of system-wide consequences and real physical limits, the internal operation of the scientific enterprise must be reevaluated. This is especially so for science in applied fields such as resource management and forestry. In place of our historical disregard for so-called "side-effects" must now come a greater respect for uncertainty in our endeavours, with a corresponding shift in the so-called legal "burden of 
proof" onto those seeking to demonstrate the environmental acceptability of new proposals.

The result should be a new caution in forestry planning that avoids introducing unsustainable practices, economic dependences and institutional structures which impede reorientation onto a sustainable path. Developing a precautionary planning approach poses great challenges to foresters who are expected, instead, to fall in line behind development schemes that are frequently driven by political and economic, not environmental, considerations. One pressing example of this scientific and professional quandary is now evident with the massive expansion in pulp mill capacity being planned for Canada's northern boreal forests, and the challenge which this large-scale growth poses even to those advocating the development of extensive forestry (Benson 1988).

In re-evaluating the certitudes of science, other forms of knowledge-especially local knowledge, including the values and insights of Canada's native peoples-deserve respect, especially to the extent to which this knowledge and expertise incorporate both a long-time horizon and an ethic of stewardship. The situation described here is a common one nationally and internationally. As a recent text on international forestry concluded:

Development planners have proceeded too boldly to exploit (tropical) forests for commodity production without adequate biological knowledge of their potential or limitations or awareness of the economic consequences of development policies...

National governments have undervalued the wisdom of traditional forest uses and the value of local traditions of forest management that they have overruled (Gillis and Repetto 1988 p.389).

An initial conclusion about the paradigm of the contemporary forester in the "age of ecology" is, therefore, the need to rethink the assumptions of our inherited scientific new values. These point, on the one hand, to the need for a critical awareness of the limits and fallibility of our science and, on the other hand, to the desirability of a greater respect in our planning for the integrity of the system of which we are a part.

\section{The Democratic Professional/Manager}

If professional training conveys technical expertise, professional practice creates elite expectations. How could it be otherwise? How, for example, can the lay person understand the methodological intricacies of calculating the Mean Annual Increment? What weight should be given to the illformed opinions of those without the requisite training and experience, especially compared with the weight assigned to the conclusions of the expert? Nevertheless, a second shift required in the forester's paradigm concerns the nature of professionalism and the role of the manager.

If our technical expertise is only as good as the critical awareness that underpins it, openness to outsiders-whether these be lay foresters, native trappers, or environmental critics -is a necessary ingredient of true professionalism. A major justification for the professional association is its role in ensuring that its members are responsible to the public, a group responsibility which again can best be ensured by a sympathetic responsiveness to public views and values. The context for an informative openness clearly exists today, as evidenced, for example, by the great success of the critical new journal, Forest Planning Canada. This journal brings innovative, and often controversial, forestry issues to the attention of a knowledgeable, and surprisingly wide, audience of foresters, environmentalists and the general public.

As part of a more open professionalism, forest management should include a more intensive, and authoritative, role for public participation. In the United States, where foresters have had to adapt to this enhanced role, two commentators note:

Agency professionals must resist the temptation to view themselves as judges who determine the merits of the contibutions of others based on a superior knowledge of forest resource management. This "expert of all experts" role is readily assumed by many public foresters because of their professional culture and because they generally have more natural resource education and experience than the other participants.... Citizens' extensive knowledge and the legitimate expression of different interests and values must be woven into the decision-making process to truly serve the public interest (Tipple and Wellman 1989, p.26-27.)

At the theoretical level, serious public involvement logically leads to a fuller range of issues and values being considered in decision-making. As we have noted, the forester/ manager operates within an institutional context that necessarily has its own agenda, based largely on business calculations. How are wider interests to be considered-such as non-monetary values, the interests of other forest users, or the needs of future generations? As Professor David Haley (1985, p.315-316) of the UBC Faculty of Forestry has written:

Justification of such widespread public intervention, at least in those countries with market economies, is market failure. That is, market prices which influence the production and consumption decisions of individuals and firms, fail to reflect the benefits and costs to society at large of forest resource use...

These (sources of market failure) include: the wide variety of non-market benefits which are provided by forest resources; the belief that market discount rates are inappropriate for evaluating investments in forestry; and the potential social costs which can arise if insufficient weight is given by firms in the private sector to community survival and stability of jobs and incomes in forest dependent regions.

Broadening the paradigm of the professional manager to include more active public participation in decision-making is also a basic conclusion of the Brundtland Commission. This is so because, as discussed above, the reality of management means contending with power. As the Commission concluded:

But many problems of resource depletion and environmental stress arise from disparities in economic and political power. An industry may get away with unacceptable levels of air and water pollution because the people who bear the brunt of it are poor and unable to complain effectively. A forest may be destroyed by excessive felling because the people living there have no alternatives or because timber contractors generally have more influence than forest dwellers.

\section{And again:}

It could be argued that the distribution of power and influence within society lies at the heart of most environment and development challenges. Hence new approaches must involve programmes...to protect vulnerable groups, and to promote local participation in decision making. (United Nations 1987 p.46 and 38). 
Models for an accomodation between industrial forestry and other forest users already exist. South of the border, in Washington, a comprehensive agreement for managing the forest resource co-operatively, the "Timber/Fish/Wildlife" agreement, was negotiated with the participation of many interests in the forest resource-native groups, environmentalists, sports fishermen, logging contractors, and state officials. As one of the leaders (Waldo 1988, p.17) of the process concluded:

But I think almost all the participants will tell you that today we're a lot better in the State of Washington than we were a year ago, regardless of which community of interest you come from. And the agreement has been ratified by virtually every environmental organization, every timber organization. It passed our State Legislature 96-0 in the House and 49-0 in the Senate. A new system was (sic) now in place and operating.

In British Columbia, such a dialogue is also possible. For example, despite the often harsh rhetoric, native leaders are not "anti-forestry" but support a dynamic, though more equitable and sustainable, forest sector (Cassidy and Dale 1989). As one native leader puts it, they espouse solutions to current land use conflicts "through discussion and negotiation....We are looking for serious, yet constructive change in the status quo. We are looking for a process by which to do it, so that no one is adversely affected" (Johns 1988 p.13).

The possibility of finding mutually beneficial solutions exists in many places where forestry conflicts exist. This is so because, to a great extent, conflicts arise from longstanding inefficiencies (which are resolvable) rather than from basic opposition of interests (which are not):

Conflict is frequent between competing interests over forest policy and is sometimes seen as inevitable.... However, an important implication of this study is that such conflict is often more apparent than real. Policies that have led to wasteful exploitation of forest resources, both in developed and developing countries, have been costly not only in biological terms, impoverishing the biota and soils, but equally costly in economic terms. Uneconomic investments have been promoted, assets have been sacrificed for a fraction of their worth, and government treasuries have been deprived of revenues and foreign exchange earnings sorely needed for genuine development purposes.

Reforms of public policies toward publicly owned forests can save both natural and financial resources. Rather than a "win-lose" predicament, opportunities for policy reform present "win-win" situations for nations with natural forest endowments (Gillis and Repetto 1988 p.394).

In short, as a corollary to the need to shift to a broader forestry science is the need for "very different kinds of organization than what we have at the moment. Our main problem in British Columbia is that we have been managing in a single-sectoral way when we have a cross-sectoral society and a crosssectoral resource" (Prescott-Allen 1989 p.6).

\section{A New Vitality}

If more democratic public involvement in forest planning can lead to a beneficial change, so too greater reliance on market forces might help resolve many of these inefficiencies that now prevent other interests from being accomodated. In British Columbia, a series of public hearings was completed this spring under the auspices of the Minister of Forests, Hon.
Dave Parker. The subject of the hearings was the proposal to convert much of the province's volume-based tenure system into area-based Tree Farm Licences, a proposal bred from a perceived need to enhance the institutional security of the industry as a basis for a more productive forest sector. To the surprise of the Minister, the hearings provoked a great outpouring of informed public concern. Local meetings, which were originally scheduled for just a few hours, often ran instead over two days, with sittings extending late into the night. Throughout the province, speaker upon speaker called for a full royal commission into the industry, a call that reflects a broad concern, not for greater security for the industry, but for a more healthy - that is, more vital and sustainable - forest economy for the province.

In focusing historically on providing security for the industry, public policies have led to the eclipse of the competitive market in forest planning. Yet market forces and democratic processes are the very foundation of our economic and political system. In many countries, major lumber manufacturers buy their raw materials on the open market, paying competitive market prices for it. This leads to higher prices for the mills but, by subjecting the process to the allocative efficiency of the market, efficiency is encouraged on two levels. First, the producers of the timber, who are separated from the mill owners (whether these be individual woodlot owners, small business operators, communities, or corporations) would have the incentive both to ensure closer utilization of the cut timber, and greater reforestation efforts because it becomes financially more remunerative to do so. Second, by paying the fuller costs of sustainable forestry, lumber mills are encouraged both to increase their lumber recovery in the milling process and to add greater value to the product. The result is more jobs in the woods (through closer utilization and more intensive forestry), and greater initiative for business development in downstream processing. Provincial revenues would rise and, with both greater reinvestment in the forest resource and increased small business diversification, such a change would foster more stable and fulfilling community economies.

By increasing efficiency, these changes also free land for other uses without necessarily leading to great detrimental impacts on the forest sector. For example, it has been demonstrated in California that an improvement in forest productivity of only $3 \%$ to $4 \%$ would free up enough land to cover all new wilderness designations proposed in the state by the federal Congress (Emerson and Helfand 1983). Similarly, it has been argued that, if British Columbia achieved the level of valueadded processing now existing in Ontario, it would add up to $\$ 6$ billion in output to the industry, less the amount accounted for by raw material importations into Ontario (Canadian Forest Service 1987). Similarly, if British Columbia generated as much employment per unit of wood as Washington state, it would create up to 60000 additional jobs (USDA 1987).

Rather than decrying the proposal for a broad wilderness system in the province, therefore, foresters should instead encourage an open enquiry into the implications of such a proposal. An enquiry could clearly delineate what was at stake: the cost that would actually result to the industry from such protective designations; the benefits to the forest industry from having such environmental/scientific areas set aside; the policies in forest management and lumber production that could be implemented to offset this land alienation; and the benefits to other economic sectors and communities from such changes. Thus, by seeking to maximize the dynamic character within the forest industry, and sympathetically evaluating the costs and benefits of a more diverse use 
of the forest base by those outside the industry, foresters might contribute positively to policy changes that can achieve a wider array of private and public interests than simply the production of wood volume for the industry. In the process, the forester's self-definition and function would change.

A concern for the preservation of old-growth timber in the United States is leading there to the development of a "new forestry" (Booth 1989). If adopted in British Columbia, the premises of this new forestry would immediately overcome one of the major differences separating foresters and environmentalists - the need to preserve representative forest lands in an undeveloped state. These are drastically underrepresented in today's park system (Roemer et al. 1988), with only $1.0 \%$ of the total prime forest land in the province being set aside for parks between 1965 and 1985 (Environment Canada 1987). Nevertheless, so as not to pose a threat to forestry, environmentalists often seek to justify proposals for new wilderness designations by arguing that they contain only small stands of timber. Might we some day hope to see the seemingly impossible: provincial foresters urging the setting aside of tracts of land for protection precisely because they do contain important stands of ecologically, as well as economically, valuable forests?

\section{Conclusion: Responsibility for Sustainability}

If the crisis of sustainability to which all politicians now give lip-service is serious, who is going to lead us to a solution? For nearly a century, foresters have fostered the growth and development of the province to its currently prosperous, but potentially unsustainable, state. For decades, environmentalists have been gnawing at the fringes of social change but without the expertise, legitimacy, or access to political power to effect sustainable changes in a systematic and planned ashion. In British Columbia, this has produced a conflict that does little to promote rational and professional management. As we face the need for a sustainable future, a "paradigm shift" is essential for such management to be implemented. This shift can best be achieved by opening up the process of forest planning to new democratic voices and to the rigours of the competitive market. With such a process, solutions which now escape attention will become obvious.

\section{Acknowledgments}

The author wishes to thank the following people for their comments on earlier drafts of the article: Chris Fletcher, Ken Lertzman, Ray Travers and Nils Zimmerman.

\section{References}

Banfield, E.C. 1959. Ends and means in planning. Int. Soc. Sci. J. 11: $361-368$.

Benson, C.A. 1988. A need for extensive forest management. For. Chron. 64: 421-430.

Boisvert, C.P. 1987. The new forest-myth or reality. Silviculture, $11(3): 4$.

Booth, W. 1989. New thinking on old growth. Science 244: 141-143.

BC Economic Accounts, 1971-1984. Government of British Columbia, Victoria, B.C.

BC Politics and Policy, 1988. Political parties differ on forest policy. 2(4): 14.

BC Ministry of Forests, 1987. Annual Report, 1986-1987. Tables D9 and D2. Victoria, B.C

Canadian Forest Service, 1987. Selected Forest Statistics Canada. Inf. Rep. E-X-38. Ottawa.

Cassidy, F. and N. Dale. 1989. After Native Claims. Oolichan Press Lantzville.

Council of Forest Industries of British Columbia. 1989. The forest industry in British Columbia, 1986-1987. A report by Price Waterhouse. Vancouver, B.C.

Emerson, P. and G. Helfand. 1983. Wilderness and Timber Production in the National Forests of California. Economic Policy Department, Wilderness Society, Washington, D.C
Environment Canada, 1987. Parks and conservation areas on prime forest land in B.C., 1965-1985. Fact Sheet 87-2. Min. Supply and Serv., Ottawa.

Forman, L. 1989. Understanding the share groups. For. Plan. Can., 5(1): $5-8$

Franklin, J. 1987. Old growth: their contribution to the commodity landscape. Guest lecture, Univ. British Columbia, January 25 , 1989.

Franklin, J.F. and R.T.T. Forman. 1987. Creating landscape patterns by forest cutting: ecological consequences and principles. Landscape Ecol. 1(1): 5-18.

Galbraith, J.K. 1967. The New Industrial State. Hamish and Hamilton, London.

Georgescu-Roegen, N. 1981. Methods in economic science: a rejoinder. J. Econ. Issues 15: 188-193.

Gillis, M. and R. Repetto. 1988. Public Policies and the Misuse of Forest Resources. Cambridge Univ Press, Cambridge.

Haley, D. 1985. The forest tenure system as a constraint on efficient timber management: problems and solutions. Can. Public Policy XI Supplement 315-320.

Harris, L. 1984. The Fragmented Forest. Univ Chicago Press, Chicago.

Holling, C.S. 1978. Adaptive Environmental Assessment and Management. John Wiley \& Sons, Chicester, England.

Hopwood, A., F. Marshall, and D. Smith. 1988. Discipline, ethics and the forestry profession in British Columbia. For. Plan. Can., 4(1): 115-125

Jacques, R. and G.A. Fraser, 1989. The forest sector's contribution to the Canadian economy. For. Chron. 65: 93-96.

Johns, E. 1988. The second way: discussion and negotiation. For. Plan. Can. 5(1): 12-13.

Larson, M.S. 1977. The Rise of Professionalism: A Sociological Analysis. University of California Press, Berkeley.

Kuhn, T. 1962. The Structure of Scientific Revolutions. Univ. Chicago Press, Chicago.

Maser, C. 1988. The Re-designed Forest. R \& E Miles, San Pedro, California.

Minkler, L.S. 1989. Coming revolutions in forestry. J. For. 87(4): 63-64.

Ombudsman of British Columbia, 1985. The Nishga Tribal Council and Tree Farm Licence No.1. Public Report No. 4. Victoria, B.C.

Outdoor Recreation Council. 1988. Adventure Travel in British Columbia. Vol. 1. Vancouver, B.C.

Pearse, Peter. 1986. The challenge of change. For. Chron. 63: 175-177.

Perry, D.A. and J. Maghembe. 1989. Ecosystem concepts and current trends in forest management: time for reappraisal. For. Ecol. Manage. 26: 123-140.

Prescott-Allen, R. 1989. Sustainable development. What is it? Do we have it? How do we get it? For. Plan. Can. 5(3): 5-6.

Roemer, H.L., J. Pojar and K.R. Joy. 1988. Protected old-growth forests in coastal British Columbia. Natural Areas J. 8(3): 146-159.

Noss, R. 1988. Strategies for conservation of old growth in the landscape. Unpublished paper presented at the Old Growth Conference, Corvallis, Oregon, August, 1988.

Schwindt, R. 1987. The British Columbia forest sector: Pros and cons of the stumpage system. Gunton and Richards (eds.), Resource Rents and Public Policy in Western Canada. The Institute for Research on Public Policy, Ottawa.

Steinbeck, K. 1988. Reflections on forestry as a profession. J. For. 86(3): 65

Tipple, T.J. and J.D. Wellman. 1989. Life in the fishbowl: Public participation rewrites public foresters' job descriptions. J. For. 87(3): 24-30.

Tourism Canada. 1988. Canadian Tourism Facts. Supply and Serv, Ottawa.

United Nations World Commission on Environment and Development 1987. Our Common Future, Oxford University Press, New York.

United States Department of Agriculture. 1987. Production, prices, employment and trade in northwestern forest industries. USDA For Serv Bull, PNW-RB-152, 3rd Quarter, 1987. Portland, Oregon.

Valhalla Society. 1988. B.C.'s Endangered Wilderness: A Comprehensive Proposal for Protection. New Denver, B.C.

Vancouver Sun, 1989. The cutting edge. April 1, 1989: D5.

Waldo, J. 1988. Redefining winning: the timber/fish/wildlife process. For. Plan. Can. (4:3): 14-19.

Webster's Ninth New Collegiate Dictionary 1987. 